Vol. 4: 473-478.

\title{
Abundance, species composition and daily pattern of bees visiting field bean, goat's rue and turnip rape in southern Finland
}

\author{
Anna-Liisa Varis \\ Department of Applied Zoology, P.O.Box 27, FIN-00014 University of Helsinki, Finland
}

\begin{abstract}
Visits of honeybees (Apis mellifera L.) and bumblebees (Bombus spp.) to flowers of field bean (Vicia faba L.), goat's rue (Galega orientalis Lam.) and spring turnip rape (Brassica rapa ssp. oleifera DC.) were studied to get some basic knowledge about the species composition, abundance and daily rhythm of bees visiting these plants. The studies were made under field conditions. Only pollinating specimens were counted. Both on field bean and goat's rue $44 \%$ of the visitors were honeybees, on turnip rape the proportion of honeybees was $96 \%$. Field bean was visited by Bombus subterraneus (L.)/B. hortorum (L.) as well as by B. lucorum (L.). These species were also present on goat's rue; the most numerous bumblebee species on this plant, however, was B. lapidarius (L.) which was also the only bumblebee species visiting turnip rape. The total number of bees was highest on goat's rue.

The visits of honeybees began on field bean at noon and were most numerous in the afternoon. On goat's rue, the numbers were smaller in the mornings, whereas turnip rape was visited at a rather constant rate throughout the day. On field bean, the numbers of B. subterraneus/B. hortorum increased and those of $B$. lucorum decreased towards the afternoon. On goat's rue, these species were present in the morning and in the afternoon. B. lapidarius was present on goat's rue during the whole day, but on turnip rape only in the mornings.

On the basis of these results and earlier investigations it is concluded that the numbers of natural pollinators are rather low to assure adequate pollination in turnip rape and large field bean areas under the conditions in southern Finland. If the growing of goat's rue becomes more prevalent, its pollination requirements need further studies.
\end{abstract}

Key words: Apidae, honeybees, bumblebees, pollination

\section{Introduction}

Field bean (Vicia faba L.) has been grown in Finland since the 16th century. It is an important domestic source of feed protein, but its acreage is very small because of great variations in yield (Varis et al. 1982b). The unstability of yields is caused mainly by weather conditions, susceptibility to diseases and pests, and possibly also by problems with pollination (e.g. Lawes 1974). Field bean is a plant where both self-pollination and cross-pollination occur. Considerable yield increases due to the actions of pollinators have been reported (Scriven 1961, Poulsen 1974, Varis and Brax 1990).

\footnotetext{
(3) Agricultural Science in Finland

Manuscript received May 1995
} 
Varis, A-L.: Bees visiting field bean, goat's rue and turnip rape

Goat's rue (Galega orientalis Lam.) is a new perennial forage legume in Finland (Varis 1986). It is a cross-pollinating plant, pollinated by insects, and was reported by Raig (1980) to be an appreciated source of honey in the former U.S.S.R.

Turnip rape (Brassica rapa $\mathrm{ssp}$. oleifera $\mathrm{L}$.) is cultivated in Finland on about 70000 hectares. It requires insects for cross-pollination and seed production although wind also contributes to its pollination. Yield increases of $10-15 \%$ or even more have been obtained from honeybee pollination under Finnish conditions (Korpela 1988).

The purpose of the present study was to assemble basic knowledge about the bumblebee species visiting field bean, goat's rue and turnip rape, as well as the abundance and daily rhythm of both bumblebees and honeybees visiting these plants. Some results of this study regarding pollination of field bean have been published earlier (Varis and Brax 1990).

\section{Material and methods}

The study was carried out on the Viikki Experimental Farm of the University of Helsinki $\left(60^{\circ} 12^{\prime} \mathrm{N}\right)$ in 1980 and was reported as part of a Master's thesis (Heinistö 1981). The spring sown field bean (cv. Mikko) and goat's rue (imported to Finland from Estonia) were both grown on an area of $500 \mathrm{~m}^{2}$ in size. The shortest distance between these areas was $100 \mathrm{~m}$. The shortest distance to the observed spring turnip rape area (cv. Span), $500 \mathrm{~m}^{2}$ in size, was about $200 \mathrm{~m}$ from field beans and $150 \mathrm{~m}$ from goat's rue. All crops were growing in the same open field on sandy clay soil, pH 6-6.5. The turnip rape observation area was situated as near as possible to the other crops on the edge of a 5.4 ha turnip rape field. A few beehives were situated at a distance of 300$500 \mathrm{~m}$ from the experimental areas, and one hive was in the field itself, close to the field bean area.

The numbers of honeybees and bumblebees were counted between 30 th June and 11th July, when all three crops flowered. Goat's rue started flowering on 15th June, turnip rape on 21 st June, and field bean on 25 th June. The bees were counted three times per day (between 9 and 10, 12 and 13,15 and $16 \mathrm{~h}$ ) in a two square metres plot in the centre of an area of $500 \mathrm{~m}^{2}$. The observer examined the plot until she identified and recorded all the bees which were there at the same time after which she moved to another area. The method with observation plots instead of counts along a transsect through the fields was chosen to avoid damaging the crops.

The counting was done only if the weather was favourable enough for bee activity which resulted in seven observation days with three countings each day. The daily mean temperature during the counting period varied from 14.3 to $18.9^{\circ} \mathrm{C}$, and the total precipitation was $2.5 \mathrm{~mm}$. On field bean only positive pollinators which visited the front of the flower for nectar or pollen were counted. To avoid misidentification, the bumblebee species Bombus hortorum and B. subterraneus were treated as one group. It must be mentioned, however, that B. subterraneus - although relatively rare in Finland - was considerably more abundant than $B$. hortorum in the local conditions in question.

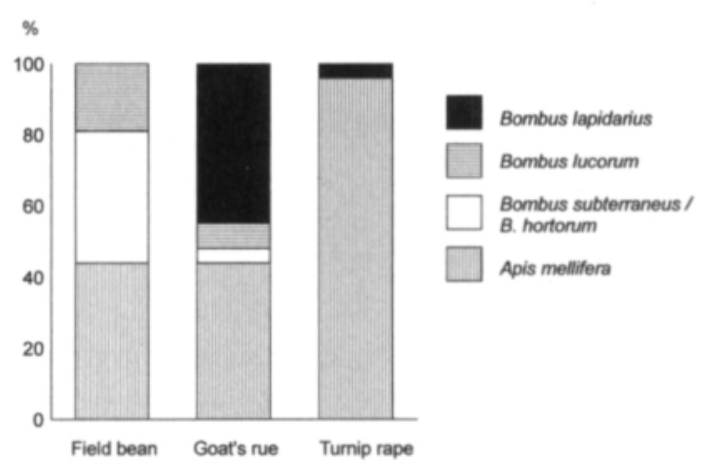

Fig. 1. Proportional abundance of different bee species on field bean, goat's rue and turnip rape in southern Finland in seven observation days between 30 th June and 11 July with three countings each day. Plot size $2 \mathrm{~m}^{2}$. 
Vol. 4: 473-478.

\section{Results}

In field bean $44 \%$ of the pollinators were honeybees, the rest being bumblebees (Fig. 1). $B$. subterraneus/B. hortorum was most numerous at about $40 \%, B$. lucorum having a minor share. The bumblebees visited field bean throughout the whole day, while the honeybees were present only from noon onwards (Fig. 2).

In goats rue, as in field bean, $44 \%$ of pollinators were honeybees, the remainder being bumblebees (Fig. 1). The most numerous bumblebee was $B$. lapidarius but both $B$. subterraneus/ $B$. hortorum and B. lucorum were also present. Goats rue was visited by bumblebees during the whole day, B. lapidarius being most active at noon. Honeybees visited goat's rue throughout the whole day being most active at noon and in the afternoon (Fig. 2).

Turnip rape was mainly visited by honeybees. The proportion of bumblebees was only $4 \%$ (Fig. 1), and only B. lapidarius was present. Honeybees were observed on turnip rape rather regularly

\begin{tabular}{lrrrr}
\hline & $\begin{array}{c}\text { Field } \\
\text { bean }\end{array}$ & $\begin{array}{l}\text { Goat's } \\
\text { rue }\end{array}$ & $\begin{array}{l}\text { Turnip } \\
\text { rape }\end{array}$ & Total \\
\hline Apis mellifera & 0.24 & 0.50 & 0.66 & 1.40 \\
\% & 17 & 36 & 47 & 100 \\
Bombus lapidarius & 0 & 0.51 & 0.03 & 0.54 \\
$\%$ & & 94 & 6 & 100 \\
B. subterraneus/ & 0.21 & 0.05 & 0 & 0.26 \\
B. hortorum \% & 81 & 19 & & 100 \\
B. lucorum & 0.11 & 0.08 & 0 & 0.19 \\
$\%$ & 58 & 42 & & 100 \\
\hline Total no/m ${ }^{2}$ & 0.56 & 1.14 & 0.69 & \\
\% & 23 & 48 & 29 & \\
\hline
\end{tabular}

Table 1. Daily mean numbers of different bee species per $\mathrm{m}^{2}$ and their percentage distribution between field bean, goat's rue and turnip rape in southern Finland in seven observation days between 30 th June and 11 th July with three countings each day. Plot size $2 \mathrm{~m}^{2}$.

during the whole day, bumblebees only in the mornings.

The total number of pollinators was highest on goat's rue (Fig. 2, Table 1). In the mornings and at noon goat's rue attracted more bees than the other plants while in the afternoon the num-

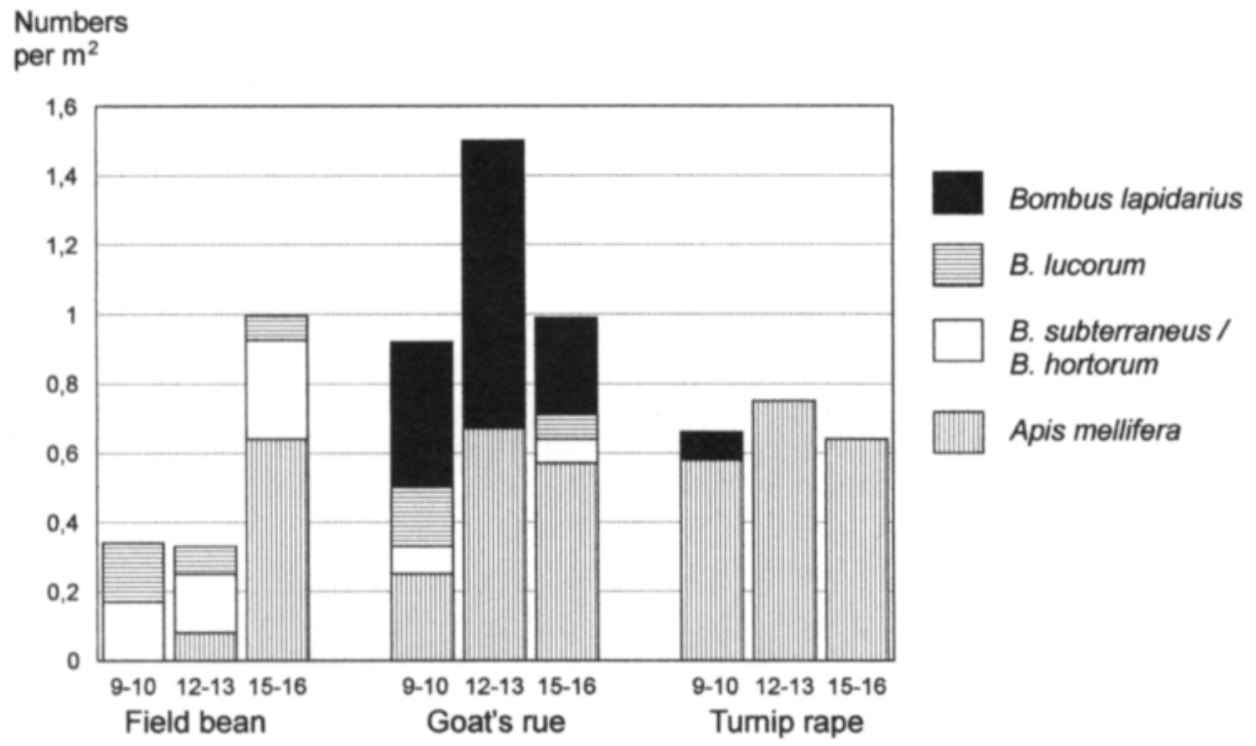

Fig. 2. Mean number of bees at different times of the day on field bean, goat's rue and turnip rape in southern Finland in seven observation days between 30 th June and 11 th July. Plot size $2 \mathrm{~m}^{2}$. 
Varis, A-L.: Bees visiting field bean, goat's rue and turnip rape

bers of all bee visitors were equal on field bean and goat's rue, their numbers on turnip rape being lowest.

In the mornings the greatest numbers of honeybees were found on turnip rape (Fig. 2), when no honeybees at all were observed on field bean. At noon, honeybees preferred turnip rape and goat's rue while in the afternoon they were distributed rather evenly on all three crops.

\section{Discussion}

In this study, honeybees and bumblebees were the only insects observed as positive pollinators of the flowers of field bean. Other insects are of no practical importance because the flower of field bean is rather big, and needs a strong insect to open it. In France (Tasei 1976), honeybees comprised $80 \%$ of the Apoidea fauna on field bean in four-year trials while the percentage of Bombus species was $14.4 \%$, the most abundant species being $B$. terrestris $8.4 \%$ and B. hortorum $3.5 \%$. The proportion of honeybees seems to be much higher than in the present study, but the numbers are not comparable, because in Tasei's (1976) study, most of the flower visits were negative, bees used holes made by robbing species and did not pollinate the flowers. However, in the present study, where only positive pollinators were counted, field bean was also visited by honeybees to a considerable extent: their numbers in the afternoons were similar to those on turnip rape, which received $96 \%$ of all visits from honeybees. From the bean flower, honeybees and short-tongued bumblebees that do not rob the nectar but enter the flower probably obtain only pollen most of the time (Free 1993). The neighbourhood of beehives undoubtedly affected the proportion of honeybees.

Goat's rue seems to be very much favoured by bees. The proportional abundance between honeybees and bumblebees was the same as on field bean (Fig. 1) but there was a difference in bumblebee species, most likely owing to the structure of the flower. The long tongued species B. subterraneus/B. hortorum were most common on field bean while $B$. lapidarius, a species with shorter tongue, was most common on goat's rue (Fig. 2).

Honeybees were the primary visitors to turnip rape. The plant is very attractive for bees and its flowers offer both nectar and pollen. Honeybees are very effective pollinators of rape because of their appropriate size for the transfer of pollen from anthers to stigma (Mc Gregor 1976). Turnip rape flowers were not visited by the longtongued bumblebee species at all. In studies of Varis et al. (1982a), Brassicaceae pollen was the most abundant pollen type in the honey of southern Finland, the main cultivation area for turnip rape.

Field bean seems to be attractive for bees mainly in the afternoon; goat's rue throughout the day, the peak being at noon. Free (1993) also recorded that honeybees visiting field bean flowers, especially for pollen, were most numerous in the afternoon, from 14 to $16 \mathrm{~h}$. The afternoon maximum of bees on field bean is caused by the fact that most of the bean pollen is presented then, and the number of field bean flowers is at its maximum in the afternoon, because all new flowers first open then (Percival 1955).

Differences in the number of visits of bees on turnip rape during the day were smaller. Some bees may collect pollen in the morning, while the nectar is more dilute, and later switch to collecting nectar, which becomes more concentrated throughout the day (Mohr and Jay 1988). On the other hand, Mohr and Jay (1990) recorded that the amount of nectar decreased during the day. The authors warn about generalizing about the foraging behaviour of honeybees on this crop as well as on Brassica napus L. because of the differences between various cultivars and different years and sites (Mohr and Jay 1988).

The mean numbers of honeybees and bumblebees at different times of the day on turnip rape, $0.58-0.75$ and $0-0.08$ specimens per $\mathrm{m}^{2}$, respectively, are in accordance with Korpela (1988). In his four-year pollination studies in other areas in South Finland, the numbers of 


\section{AGRICULTURAL SCIENCE IN FINLAND}

Vol. 4: 473-478.

honeybees and bumblebees in open plots were normally $0.19-0.95$, and $0.01-0.09$, respectively. On the basis of his results Korpela (1988) concluded that only beehives in the immediate neighbourhood of turnip rape normally assure adequate number of pollinators. In the present study the corresponding values on field bean were $0-0.64$ and $0.25-0.36$ specimens per $\mathrm{m}^{2}$ for honeybees and bumblebees, respectively. On the basis of pollination studies carried out contemporaneously with the countings presented in this study, Varis and Brax (1990) suggested that in large field bean areas where the number of wild bees is lower, the role of honeybees is emphasized.

On goat's rue the numbers of honeybees and bumblebees were $0.25-0.67$ and $0.43-0.83$ specimens per $\mathrm{m}^{2}$, respectively. Because no pollination studies on this plant are available, no conclusions can be made about the adequacy of the pollinators. If the growing of goat's rue becomes more popular in Finland, studies are needed to investigate its pollination requirements.

In this study the turnip rape field was larger than the areas of other studied crops, and there were two other turnip rape blocks, 15.4 ha in total, further away from the experimental area in an open field area of about 200 hectares. However, the observation area was as close to field bean and goat's rue areas as possible, and it is known that bees tend to fly as short a foraging distance as possible (Free 1990). In the field open there were also many other plants such as Trifolium spp., Chamaenerion angustifolium (L.) Scop., Vicia cracca L. and Knautia arvensis L. flowering during the same period. In agricultural areas in Finland there is normally a great diversity of plants in the flying area of bees. The results of this study reflect the situation between three crops in normal agricultural conditions.

\section{References}

Free, J.B. 1993. Insect pollination of crop plants. 2 ed. 684 pp. Academic Press, London.

Heinistö, R. 1981. Mehiläisen osuus hărkăpavun (Vicia faba L.) sadonmuodostuksessa ja härkäpavun merkitys mehiläisen satokasvina. Mimeogr. 75 p. (Available at the Department of Applied Zoology, University of Helsinki).

Korpela, S. 1988. The influence of honeybee pollination on turnip rape (Brassica campestris) yield and yield components. (Finnish summary). Annales Agriculturae Fenniae 27: 295-303.

Lawes, D.A. 1974. Field beans: improving yield and reliability. Span 17: 21-23.

McGregor, S. 1976. Insect pollination of cultivated crop plants. 411 p. Washington D.C.

Mohr, N.A. \& Jay, S.C. 1988. Nectar- and pollen-collecting behaviour of honeybees on canola (Brassica campestris L. and Brassica napus L.). Journal of Apicultural Research 27(2): 131-136.

- \& Jay, S.C. 1990. Nectar production of selected cultivars of Brassica campestris L. and Brassica napus L. Journal of Apicultural Research 29(2): 95-100.

Percival, M.S. 1955. The presentation of pollen in certain angiosperms and its collection by Apis mellifera. New Phytologist 54: 353-368.

Poulsen, M.H. 1974. Pollination, seed setting, cross fer- tilization and inbreeding of Vicia faba L. Zeitschrift für Pflanzenzüchtung 74: 97-118.

Raig, H. 1980. Sōődagaleega kasvatamine ja kasutamine. 64 p. Tallinna. Valgus.

Scriven, W.A. 1961. Pollination of field beans. Outlook on Agriculture 3: 69-75.

Tasei, J.N. 1976. Les insects pollinisateurs de la féverole d'hiver (Vicia faba equina L.) et la pollinisation des plantes mâle-stérile en production de semence hybride. Apidologie 7: 1-38.

Varis, A.-L. \& Brax, R. 1990. Effect of bee pollination on yield and yield components of field bean (Vicia faba L.). Journal of Agricultural Science in Finland 62: 45-49.

-, Helenius, J. \& Koivulehto, K. 1982a. Pollen spectrum of Finnish honey. Journal of the Scientific Agricultural Society of Finland 54: 403-420.

Varis, E. 1986. Goat's rue (Galega orientalis Lam.), a potential pasture legume for temperate conditions. Journal of Agricultural Science in Finland 58: 83-101.

-, Hovinen, S., Kansanen, P. \& Kauppila, R. 1982b. Legumes in Finnish agriculture. Finnish National Fund for Research Development. Nitrogen project. Rep. 1: 219-231. Helsinki. 


\title{
AGRICULTURAL SCIENCE IN FINLAND
}

Varis, A-L.: Bees visiting field bean, goat's rue and turnip rape

\section{SELOSTUS}

\section{Mehiläiset ja kimalaiset härkäpavun, vuohenherneen ja rypsin pölyttäjinä}

\author{
Anna-Liisa Varis \\ Helsingin yliopisto
}

Mehiläisten ja kimalaisten kukissakäynnin runsautta ja kimalaislajistoa selvitettiin Helsingin yliopiston Viikin opetus- ja tutkimustilan härkäpapu-, vuohenherne- ja rypsikasvustoissa. Laskennat tehtiin heinäkuun alkupuolella, jolloin kaikki kolme kasvia olivat kukassa. Kasvustojen läheisyydessä oli joitakin mehiläispesiä. Kun härkäpavulla lyhytkieliset mesipistiäislajit voivat ryöstää meden teriön torveen tekemästään reiästä tai käyttää muiden lajien tekemiä reikiä, laskennassa otettiin huomioon vain yksilöt, jotka keräsivät mettä tai siitepölyä kukan etuosan kautta aiheuttaen samalla pölytyksen.

Sekä härkäpavun että vuohenherneen kukissa vierailleiden mehiläisten ja kimalaisten yhteismäärästä $44 \%$ oli mehiläisiä, rypsillä mehiläisten osuus oli $96 \%$. Härkäpavun kelpaavuutta mehiläisille kuvastaa se, että iltapäivisin mehiläisiä oli sillä yhtä paljon kuin mehiläisten suosimalla rypsillä. Härkäpavul- la vierailivat kimalaisista pitkäkieliset maakimalaiset/tarhakimalaiset sekä lyhytkieliset mantukimalaiset.

Mehiläisten ja kimalaisten yhteismäärä oli suurin vuohenherneellä. Hehtaaria kohti laskettuna määrä oli tarkastuspäivinä keskimäärin yli 11000 yksilöä, kun se rypsillä oli 6900 ja härkäpavulla 5600 . Vuohenherneellä mehiläisten ja kimalaisten keskinäiset lukumääräsuhteet olivat samat kuin härkäpavulla. Kimalaislajisto oli kuitenkin erilainen siten, että lyhytkielisemmät lajit suosivat vuohenhernettä, pitkäkielisemmät härkäpapua. Vuohenherneen kimalaisvieraista yleisin oli kivikkokimalainen.

Rypsin kukkien rakenteesta johtuen mehiläiset sopivat kimalaisia paremmin niiden pölyttäjiksi. Ainoana kimalaislajina kukissa vieraili kivikkokimalainen. 